\title{
SOCIAL MEDIA AND COVID-19 NEWS SHARING: KEEPING POLITICAL ANTECEDENTS IN PERSPECTIVE
}

\author{
Rehan Tariq \\ Lecturer, Department of Mass Communication, \\ Government College University Faisalabad \\ rehantariq@gcuf.edu.pk
}

Sobia Shahzad

Assistant Professor, Department of Mass Communication, Government College University Faisalabad sobiashahzad@gcuf.edu.pk

\section{Izzal Asnira Zolkepli}

Senior Lecturer, School of Communication, Universiti Sains Malaysia

izzalasnira@usm.my

\begin{abstract}
COVID-19 pandemic has piqued the research interest of medical professionals and social scientists. In social sciences COVID-19 based political campaigns and trends on social media have extended their implications in the domain of political communication. The dissemination of COVID-19 news on social media is widespread, however, the political factors influencing the spread of such news are less discussed. To explore these factors, we evaluated empirical data from 390 social media users in Pakistan by applying PLS-SEM modeling. Snowball sampling was implied to collect the data. Political interest, partisanship, political knowledge, and political efficacy were incorporated as antecedents of COVID-19 news sharing on social media. Major findings show political interest as the most significant antecedent of COVID-19 news sharing followed by political knowledge and partisanship. However, political efficacy did not display any significant influence on participants' intentions of sharing COVID-19 news via social media. Based on the findings, theoretical and policy implications are suggested.
\end{abstract}

Keywords: Social Media; COVID-19 News Sharing; Political Interest; Partisanship; Political Knowledge; Political Efficacy

\section{INTRODUCTION}

COVID-19 is a continuing threat for international public health which has ramified into economic, psychological and sociopolitical spheres. Whether we talk about infection and death or the scope of public health interventions such as mobility restrictions, economic insecurities, and public sector spending, all have staggering statistics. Global economy is being forced into medically induced comas, health facilities have been chocked, and governments have to take tough and unpopular public health measures (Greer et al., 2020). Unemployment (Blustein et al., 2020), food crisis (Toffolutti et al., 2020), and shortage of medicines (Romano et al., 2021) developed catastrophic situation. While this infection was posing a serious risk, politicization of the COVID-19 pandemic grabbed the attention, and public view has been divided along political ideological lines. The politicization of COVID-19 news coverage further amplified the political influences and widened these political lines. Meanwhile, the penetration of social media among masses proliferated the spread and effect of COVID-19 related news (Ward et al., 2020).

The diffusion of COVID-19 information via social media venues developed multiple perceptions about its role and kind of information shared on it. Marin (2020) in an exploration of COVID-19 infodemic identified a significant information disorder and enlisted the available information on social media into erroneous, misleading, and inappropriate. The circulation of fake news and misinformation through social media is quicker than accurate and reliable information. Such 
rapid spread of misinformation is causing damage to health system and harming the mental health of its users (Radwan et al., 2020). On the other hand, social media, when utilized intelligently and sensibly, may be a powerful instrument for encouraging individual and national health wellbeing and altering people's behavior. Such a responsible use of social media can be helpful in convincing people to opt non-pharmaceutical interventions (NPIs) such as remote or online working, social distancing, mask wearing, and avoiding public gatherings (Sahni \& Sharma, 2020).

It is believed that highly polarized political behaviors and beliefs cause news sharing on social media forums and similar trend is observed in COVID-19 news sharing (Bridgman et al., 2020). Without a grasp of policy and politics, it will be difficult to comprehend the contrasting responses to COVID-19 information and its consequences. This situation emphasizes on the need to collaborate the political dimensions of public health issues. The dissociation between political scientists and public health practitioners is much bemoaned and need to be addressed (Greer et al., 2020). The dramatic rise of COVID-19 news sharing necessitates considerable research to understand the political motivations for COVID-19 news dissemination via social media. Although literature is growing on COVID-19 news sharing but the existing literature is focusing on fake news (Apuke \& Omar, 2020, 2021) and unverified information sharing (Bridgman et al., 2020; Laato et al., 2020; Radwan et al., 2020). It is yet to be explored what are the political orientations of social media users that inspire them to share COVID-19 news. Undoubtedly, politically loaded messages play significant role in developing public perception on specific issue (Bridgman et al., 2020).

\section{Political Pandemic and Social Media}

COVID-19's first case was reported in Wuhan, China, in December 2019. Almost after a month World Health Organization (WHO) issued an alert for all governments to "be prepared" to curtail the transmission of virus in their countries. Countries like Japan and South Korea gave swift response and took immediate actions to restrict the spread. But Donald Trump, US President at that time, initially overlooked and politicized the virus, criticized WHO, issued false reassurances, and delayed federal actions (Yamey \& Gonsalves, 2020). Trump massively used Twitter to introduce COVID-19 as identity based virus by calling it "Chinese Virus" (Davey, 2020). Donald Trump consistently utilized social media, especially Twitter, to disseminate conspiracy theories and far right political ideology regarding COVID-19 among his followers. Politicization of the global health crisis intensified the risk and harmed the public health (Fuchs, 2021). According to WHO statistics 759,388 Americans lost their life (World Health Organization, 2021). China, on the other hand, successfully controlled the spread after taking strict movement control measures. The most recent figures reported 5697 deaths in China caused by COVID-19 (World Health Organisation, 2021).

In Pakistan, the first COVID-19 case was reported on February 26,2020. There was an ample time for the state to prepare to face the inevitable spread, but the inconsistent government policies, careless attitude, and fatalistic statements of government officials by calling COVID-19 a mild flue developed a careless attitude in public (Naseem, 2020). As a result Pakistani government, while experiencing an inevitable COVID-19 spike, had to deploy military across the country to deal with the health crisis (Hussain, 2020). At the same time toxic trends on Twitter blaming religious and political rivals for causing COVID-19 spread in Pakistan was observed (Gannon, 2020). Ittefaq et al., (2020), in their research on COVID-19 and social politics in Pakistan, illustrated that massive sharing of COVID-19 content in political context was observed in the form of WhatsApp messages and social media news feeds. However, the political motivations for sharing such content have yet to be known. Therefore, in this study we addressed this gap. The novelty of this study is that it integrates social cognitive theory and uses and gratification theory to extend the literature on political antecedents of COVID-19 news sharing on social media during global health crisis.

Social media use in COVID-19 perspective is well researched. However, most of the studies have explored the social, psychological and health risks of COVID-19 among social media users. For instance, in their study, Mahmood et al. (2021), found a positive role of social media use in creating perceived threat of COVID-19 and self-efficacy which ultimately results in preventive behavior among social media users. A huge body of research has investigated the spread of fake news and diffusion of misinformation online in response to the coronavirus pandemic (Apuke \& Omar, 2020, Lobato et al., 2020). However, it has been observed that previous literature in the domain of political communication has rarely explored the political antecedents which motivates social media users to share COVID-19 news. Furthermore, most of the political models of COVID-19 news sharing are 
tested in developed countries of Europe and America. This limits the implication of the available research to a specific region (Grossman et al., 2020). Therefore, we were motivated to explore another context. Consequently we tested highly polarized Pakistani society (Bilal et al., 2019) to test the political antecedents of COVID-19 news sharing behavior among social media users. Another rationale for choosing Pakistan was derived from the fact that the government of Pakistan's confused COVID-19 response and contradictory policies prompted the formation and penetration of politically loaded media rumors (Khattak, 2020). These rumors later caused panic and fear in public (Ittefaq et al., 2020). Therefore, to understand the political antecedents of COVID-19 news sharing in Pakistan we designed a holistic model based on the social cognitive theory and uses and gratification Theory.

\section{Theoretical Underpinnings}

The current study devised a conceptual model by integrating Social Cognitive Theory (SCT) and Uses and Gratification Theory (UGT). Social Learning Theory of Bandura (1977), provided the theoretical roots for SCT. Bandura extended his research with the title of Social Cognitive Theory. In his book, Social Foundations of Thought and Action: A Social Cognitive Theory, Bandura (1986) argued that human behaviours are consequent upon personal, behavioural and environmental stimulus. Later, SCT, linked with mass communication and addressed reciprocal connection among personal, behavioural and environmental determinants of human thoughts. The conceptual framework of SCT, analysed that through the process of symbolic interaction and psychological mechanism human thoughts and actions are determined which collectively cause behavioural change (Bandura, 2001).

Bandura (1977b) predicts self-efficacy as strong predictor of behavioural change with strong influence on choice of activities. SCT, documented self-efficacy as people's confidence in their competence to get desired outcomes by executing appropriate course of action (LaRose \& Eastin, 2004). In domain of democratic politics, political efficacy is utilized to extract citizen's political involvement. Politically efficacious society depends upon the people's understanding of political issues (Kalirajan et al., 2013) and their confidence in political knowledge. Consequently, individual with great political knowledge possess high level of efficacy in politics, that ultimately leads towards political activism (Wei \& Zhao, 2017). Bandura (1995) in an illustration of the identification component of SCT illustrated that people used to follow the identical behaviours. The greater the apparent similarities or emotional linkages the more likely the observer would repeat the behaviour. Turner (2010) further proved the psychological roots of in group and out group identity phenomenon in the light of SCT. Therefore, this study utilized social cognitive theory to investigate the political cognitions of political knowledge, political efficacy, and partisanship.

To further strengthen the theoretical grounds, the Uses and Gratification Theory was utilized to investigate the political interest in proposed model. This theoretical approach proclaims that people have specific motivations for media use that eventually gratify their specific needs. $U$ \& G theory further expounds the usage patterns of media audience and answers the key questions; why individuals prefer certain media, what type of needs are fulfilled by using a typical media and how individuals gratify themselves after specific media consumption? Emerged in 1940, the U\&G theory stands out among other media theories by distinguishing the media audience as active users rather considering them passive individuals (Katz et al., 1974). The theory further classifies the drives behind media use into four broad typologies: surveillance motivation, leisure motivation, personal identity motivation, and motivation for building social linkages (Katz et al., 1974). Initially, scientists widely applied the theory to traditional media uses while a huge body of subsequent research include internet under the domain of uses and gratification. More recently, viewing social media uses through the lens of uses and gratification is a growing concern of social scientists.

Keeping $U$ \& $\mathrm{G}$ in perspective, people are generally mindful of their particular needs (Rubin, 2009) and they want to gratify those needs. Such as, media users may feel a need to be politically informed or they may have a need to be relaxed. For gratification of the needs, they may opt for a specific media among other options (Knoll et al., 2020). Hence, a specific media use depends on the type of need a user feel (Rosengren, 1974). Overall, individuals' psychological and physical requirements are the main determinants of their needs while taking care of their internal and external dispositions (Rosengren, 1974). All personal characteristics of an individual, for instance, his age, gender, feelings, lifelong preferences, and other personality traits developed throughout his life, comes under internal dispositions. Political interest of an individual serve as a clear example of internal disposition (Rosengren, 1974). Simply put, there is an enhanced motivation of news sharing if 
someone has greater interest in politics. Moreover, the importance of predispositions in determining how motivated people are for receiving a particular political information is well established (Knoll et al., 2020). Thus, the current study added political interest in the model under the concept of personal disposition; a subtype of uses and gratification theory.

\section{Developing the Research Model}

This study intends to understand the determinants of COVID-19 news sharing behaviour in social media and how they are influenced by the political cognition. The research model is developed by combining SCT, U \& G theory, and inferences from past literature. Political cognitive antecedents include partisanship, political efficacy and political knowledge. Whereas, political interest is investigated under $U$ \& G perspective. Current study hypothesized the relationship of aforementioned antecedents with COVID-19 news sharing via social media.

Past literature (e.g., Park et al., 2009; Strömbäck et al., 2012; Karnowski et al., 2018) has consistently shown that political interest and news sharing on social media associate with each other. Strömbäck et al. (2012) in a longitudinal analysis proved an increase in the strength of association between political interest and news use. Similarly, Karnowski et al. (2018), in a cross-sectional study on Twitter and Facebook subscribers, reached a similar conclusion that political interest is significantly related to news sharing behaviour. If political interest posits positive impact on news sharing, it is plausible that it also has similar impact on COVID-19 news sharing. Therefore, the proposed hypothesis of this study is as follows:

H1: Political interest will significantly influence the user's intention to share COVID-19 news on social media.

Furthermore, partisanship is significant in the evaluation of social media political content. Such evaluation motivates people to share the content in their own sphere of interest (Ardèvol-Abreu et al., 2017). Also, because party image and party support are often evaluated on social media platforms, political partisans provoke people for sharing political content including news that support their political party (Huddy et al., 2010). This study expects similar political behaviour with reference to COVID-19 news sharing on social media. Thereby, we predict the following hypothesis:

H2: Partisanship will significantly influence the user's intention to share COVID-19 news on social media.

Sense of being knowledgeable fosters feeling of empowerment that, in political domain, motivates people to reinforce political cognition (Chen \& Chan, 2017). Social media as a source of news has always been positively associated with political knowledge (And1 et al., 2020). Does news content on social media enhance political knowledge of users? This old question, because of the swift change in political information environment, has piqued the curiosity of the new scholars to address it in a different way (van Erkel \& Aelst, 2021). In response to this request, we aimed to explore it as a reciprocal relationship. Most recently it has been observed that social media is widely used for rapid information dissemination during COVID-19 pandemic (Chan et al., 2020). In this context, we proposed the following hypothesis:

H3: Political knowledge will significantly influence the user's intention to share COVID-19 news on social media.

Political efficacy as a self-perception of having enough understanding and capability to participate in political activities has mostly been associated with political activities on social media (Park \& Kaye, 2018). In a recent study Lu and Luqiu (2020) while advancing the understanding on mechanism of news engagement concludes that political efficacy and news engagement are positively associated with each other, encompassing liking, commenting and sharing. The existing literature motivated us to hypothesize the following statement:

H4: Political efficacy will significantly influence the user's intention to share COVID-19 news on social media.

Figure 1 demonstrates the model we formulated using the literature. 


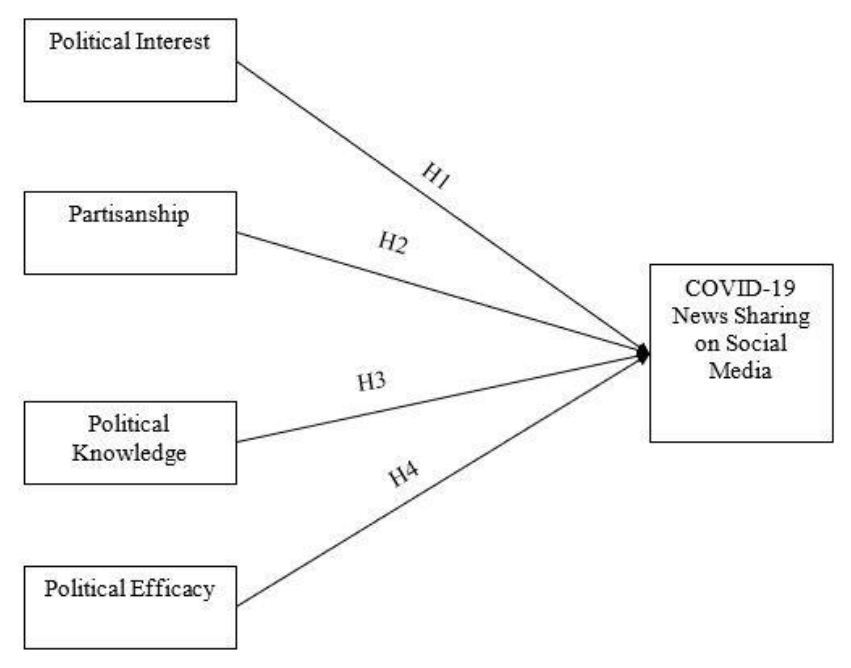

Figure 1. Conceptual model for COVID-19 news sharing

\section{METHODS AND MEASURES}

\section{Data Collection}

We used online survey by creating a Google form to test the proposed research model. Snowball sampling was used to recruit participants aged 18 years and above who use social media from Pakistani population. Snowball sampling was suitable because the sample frame did not work, and the population members were difficult to locate in the field (Bobbie, 2013) because of the COVID-19 spread. Sample size of 385 was calculated on Raosoft@ sample size calculator with $5 \%$ margin of error (Raosoft, 2004). We collected the data in mid-2021 and received 390 valid responses. Table 1 illustrates the personal particulars of the respondents.

Table No. 1: Sample Demographic Information $(N=390)$

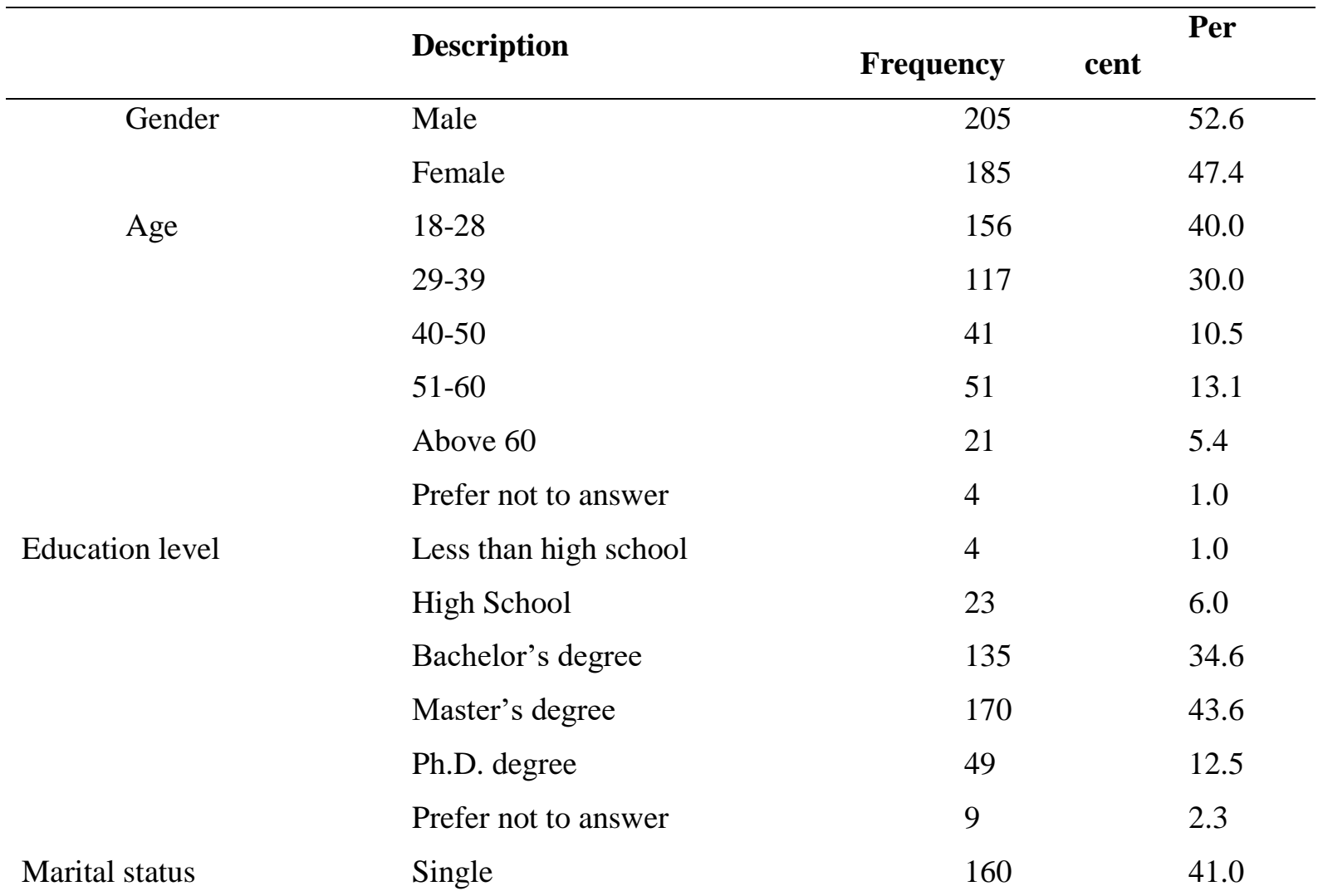


Tariq, Shahzad, \& Zolkepli

$\begin{array}{llll} & \text { Married } & 196 & 50.3 \\ \text { Divorced } & 12 & 3.1 \\ \text { Widowed } & 4 & 1.0 \\ \text { Employment detail } & \text { Prefer not to answer } & 18 & 4.6 \\ & \text { Full-time } & 165 & 42.3 \\ & \text { Part-time } & 27 & 7.0 \\ \text { Self-employed } & 41 & 10.5 \\ \text { Student } & 135 & 34.6 \\ \text { Retired } & 13 & 3.3 \\ & \text { Prefer not to answer } & 9 & 2.3\end{array}$

\section{Measurement}

Political interest in this study refers to respondents' attention towards political news and current affairs and seeking political information from an everyday social media communication. Respondents' were asked to record their answers on 5 point Likert scale, adapted from Bimber et al. (2015), Becker and Copeland (2016), and Himelboim et al. (2012). Likert scale was ranged from strongly disagree to strongly agree.

Partisanship refers the strength of attachment of an individual for a particular political party. We measured partisan strength of respondents on six item measurement scale adapted from the studies of Huddy et al. (2010) and Chan (2018). A 5-point Likert scale ranging from weak to extremely strong was used to record the responses of participants.

Political knowledge in this study is depicted as perceived political knowledge that refers to participants' perception on their own level of information about parties, leadership, issues and current political alignments. Seven items to measure this construct were adapted from the empirical studies of Mustapha and Omar (2020), and Skoric and Zhang (2019). Participants' response was recorded on 5point Likert scale.

Political efficacy refers to participants' self-perception on their political competence and ability to participate in relevant political activities. We adopted six items from the studies of Yamamoto et al. (2017) and Pei et al. (2018) to measure the respondents efficacy on a 5 point Likert scale which ranged from strongly disagree to strongly agree.

COVID-19 news sharing refers to the practice of sharing COVID-19 information with people via social media venues. The measurement scale, consisting of seven items, to measure this construct was adapted from Thompson et al. (2020)'s study on news sharing behaviour on social media. Respondents were asked to record their response on 5-point Likert scale from strongly disagree to strongly agree.

\section{RESULTS}

Partial least square structural equation modelling (PLS-SEM) was employed to analyze the proposed research model. Smart PLS 3.3.3 was used to validate the assessment of measurement and structural model. Smart PLS, developed by Ringle et al. (2005), has been widely used in scientific inquiry and exploring the complicated relationship between constructs (Ringle et al., 2014). Prior to evaluate the measurement model, it is necessary to determine the collinearity for single source data. To accomplish this, we examined the variance inflation factor (VIF), displayed in Table 2. The acceptable threshold value of VIF is five or less, as directed by Hair et al. (2011).

Table No. 2 Full Collinearity Test.

\begin{tabular}{ll}
\hline Constructs & COVID-19 news sharing \\
\hline COVID-19 news sharing & \\
Partisanship & 2.308 \\
Political knowledge & 3.639 \\
Political efficacy & 3.753 \\
\hline
\end{tabular}




\begin{abstract}
Political interest 1.269

\section{Measurement Model Assessment}

To assess the measurement model, this study examined three things which are internal consistency reliability, convergent validity, and discriminant validity. To meet the convergent validity criterion, first we checked the item loadings and found that loadings successfully met the threshold level of 0.7 (Hair et al., 2017). Afterwards, the average variance extracted was explored that confirmed that AVE values for the constructs of present study are greater than 0.5 (See Table 3). Then, we confirmed the internal consistency reliability. Cronbach's alpha $(\alpha>0.60)$ (Sekaran \& Bougie, 2020), composite reliability (CR > 0.70) (Hair et al., 2017), and rho_A ( $\rho A>0.70)$ (Henseler et al., 2016) are the criteria referred to determine internal consistency reliability. The results in Table 3 illustrate that internal consistency criteria are successfully met. Table 4 shows that AVE's square roots for each construct at the top surpassed the correlations with other constructs (Fornell \& Larcker, 1981). HTMT for each construct, in Table 5, is also lower than 0.90 (Henseler et al., 2015). Therefore, the study data had no issue of discriminant validity.
\end{abstract}

Table No. 3 Internal Consistency Reliability and Convergent Validity

\begin{tabular}{|c|c|c|c|c|c|c|}
\hline & Items & Loadings & $\mathbf{C A}$ & rho_A & CR & AVE \\
\hline \multirow[t]{6}{*}{ Political Interest } & PI1 & 0.5 & 0.926 & 0.926 & 0.942 & 0.73 \\
\hline & PI2 & 0.876 & & & & \\
\hline & PI3 & 0.863 & & & & \\
\hline & PI4 & 0.873 & & & & \\
\hline & PI5 & 0.831 & & & & \\
\hline & PI6 & 0.835 & & & & \\
\hline \multirow[t]{6}{*}{ Partisanship } & PS1 & 0.915 & 0.958 & 0.959 & 0.966 & 0.825 \\
\hline & PS2 & 0.924 & & & & \\
\hline & PS3 & 0.893 & & & & \\
\hline & PS4 & 0.916 & & & & \\
\hline & PS5 & 0.906 & & & & \\
\hline & PS6 & 0.895 & & & & \\
\hline Political & PPK1 & 0.832 & 0.939 & 0.942 & 0.95 & 0.732 \\
\hline \multirow[t]{6}{*}{ Knowledge } & PPK2 & 0.888 & & & & \\
\hline & PPK3 & 0.854 & & & & \\
\hline & PPK4 & 0.858 & & & & \\
\hline & PPK5 & 0.837 & & & & \\
\hline & PPK6 & 0.86 & & & & \\
\hline & PPK7 & 0.859 & & & & \\
\hline \multirow[t]{6}{*}{ Political Efficacy } & PEF1 & 0.873 & 0.938 & 0.941 & 0.951 & 0.764 \\
\hline & PEF2 & 0.851 & & & & \\
\hline & PEF3 & 0.924 & & & & \\
\hline & PEF4 & 0.875 & & & & \\
\hline & PEF5 & 0.811 & & & & \\
\hline & PEF6 & 0.906 & & & & \\
\hline \multirow{7}{*}{$\begin{array}{l}\text { COVID-19 News } \\
\text { Sharing on Social } \\
\text { Media }\end{array}$} & CNS1 & 0.81 & 0.935 & 0.936 & 0.947 & 0.72 \\
\hline & CNS2 & 0.858 & & & & \\
\hline & CNS3 & 0.774 & & & & \\
\hline & CNS4 & 0.852 & & & & \\
\hline & CNS5 & 0.897 & & & & \\
\hline & CNS6 & 0.9 & & & & \\
\hline & CNS7 & 0.843 & & & & \\
\hline
\end{tabular}


Table No. 4 Discriminant validity (Fornell-Larcker criterion).

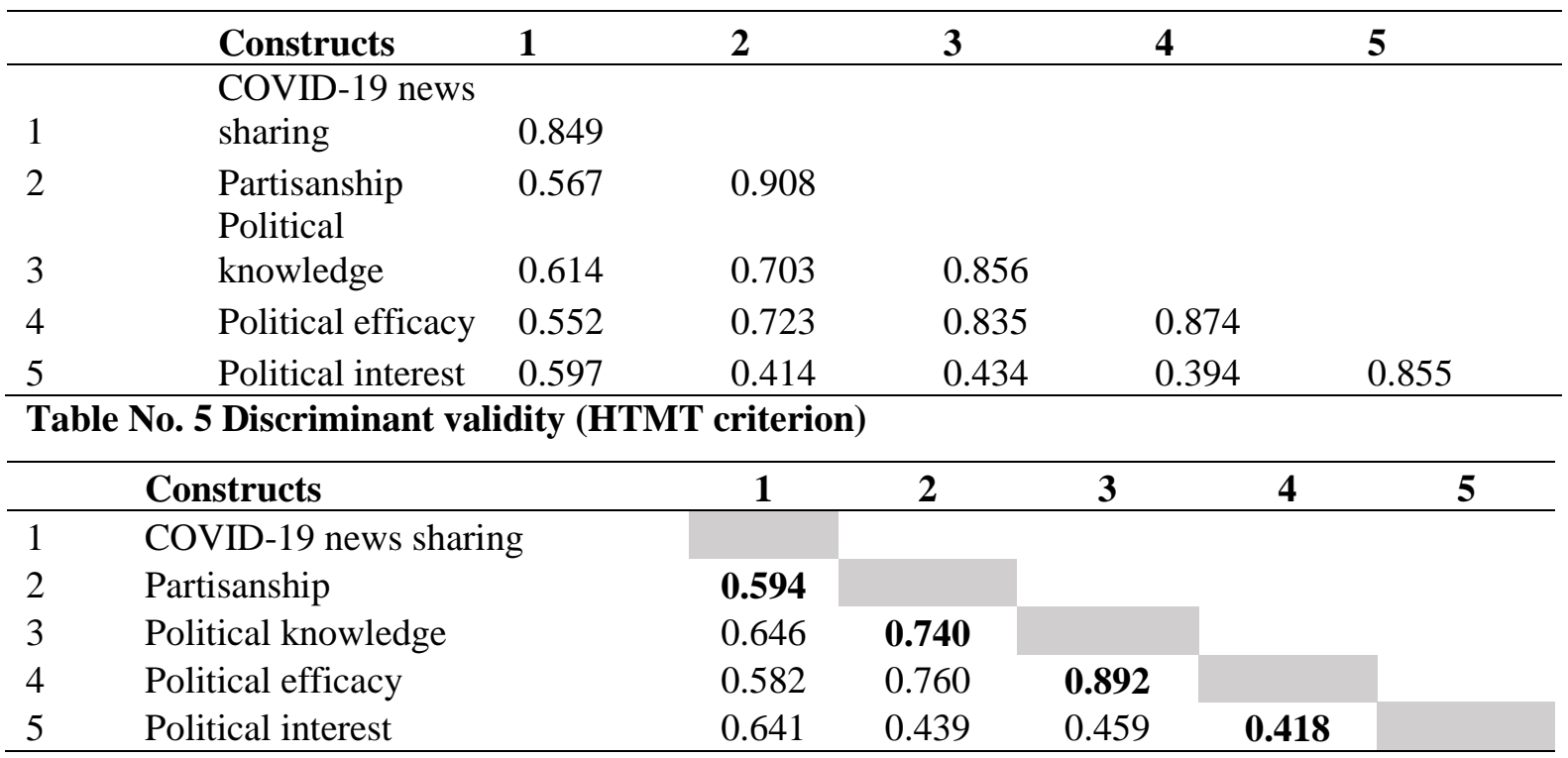

\section{Structural Model Assessment}

After fulfilling the measurement model criteria, we assessed structural model. Structural model helps to elaborate the hypothesized relationship between constructs (Hair et al., 2017). To test the significance of relationship we run the bootstrapping of 390 cases with 5000 samples, 5\% significance level, and two-tailed test option. For the structural model we tabulated (See Table 6) the path coefficient ( $\beta$ ), level of significance ( $p$-value), the confidence interval bias corrected (CIBC), and the $\mathrm{t}$-value as per recommendations of Ramayah et al. (2018).

Table No. 6 Results of the Structural Model Assessment.

\begin{tabular}{|c|c|c|c|c|c|c|}
\hline \multirow[t]{2}{*}{$\begin{array}{l}\text { Hypothesised } \\
\text { Relationship }\end{array}$} & \multirow[t]{2}{*}{$\beta$ Value } & \multirow[t]{2}{*}{$t$-Value } & \multirow[t]{2}{*}{$p$-Values } & \multicolumn{2}{|c|}{$\begin{array}{l}\text { Confidence Interval } \\
\text { Bias Corrected }\end{array}$} & \multirow[t]{2}{*}{ Results } \\
\hline & & & & $2.5 \%$ & $97.5 \%$ & \\
\hline PI $\rightarrow$ CNS & 0.383 & 8.480 & $0.000^{* * *}$ & 0.296 & 0.473 & Accepted \\
\hline PS $->$ CNS & 0.182 & 3.344 & $0.001 * *$ & 0.075 & 0.287 & Accepted \\
\hline PK -> CNS & 0.314 & 4.556 & $0.000 * * *$ & 0.173 & 0.445 & Accepted \\
\hline $\mathrm{PEF}->\mathrm{CNS}$ & 0.008 & 0.113 & 0.910 & -0.134 & 0.145 & Rejected \\
\hline
\end{tabular}

Note: Significant at $p<0.05^{*}, p<0.01, * *$ and $p<0.001 * * *$.

Our results demonstrate acceptance of three hypotheses whereas one hypothesis is rejected. Political interest $(\beta=0.383, p=0.000, \mathrm{t}=8.480)$, partisanship $(\beta=0.182, p=0.001, \mathrm{t}=3.344)$, and political knowledge $(\beta=0.314, p=0.000, t=4.556)$ showed positive and significant influence on the COVID-19 news sharing on social media. However, political efficacy $(\beta=0.008, \mathrm{p}=0.910, \mathrm{t}=$ 0.113 ) did not display any impact on COVID-19 news sharing behaviour on social media. We also examined the coefficient of determination $\left(\mathrm{R}^{2}\right)$ that explains the percentage variance in the exogenous construct and the predictive accuracy of the model. (Hair et al., 2017). The R2 value of COVID-19 news sharing on social media is 0.529 , which depicts that our exogenous construct explains $52.9 \%$ of the variance that is moderate and satisfactory (Ramayah et al., 2018). Figure 2 illustrates the assessment of structural model. 


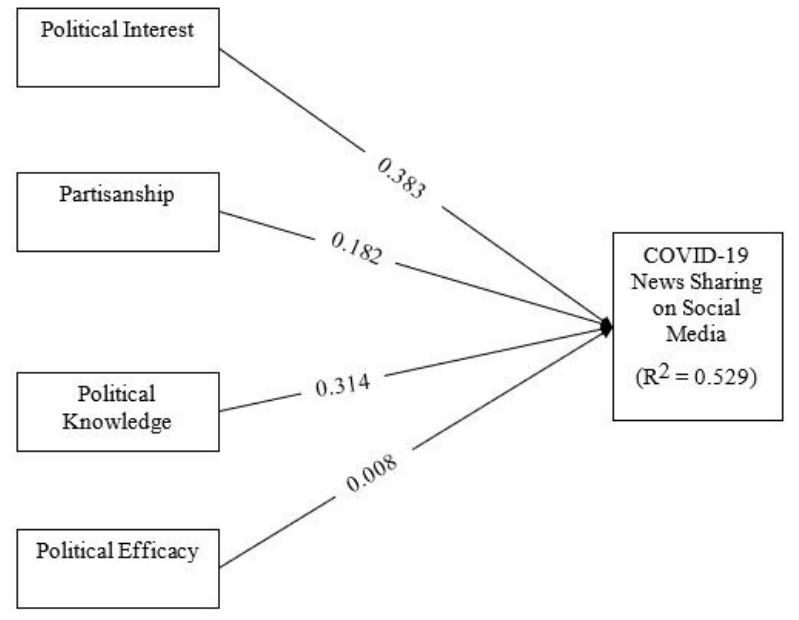

Figure 2. Political model of COVID-19 news sharing

\section{DISCUSSION}

Our study illustrated political antecedents of COVID-19 news sharing using the Social Cognitive Theory and Uses and Gratification Theory. The constructs incorporated as political antecedents including political interest, partisanship, political knowledge, and political efficacy. Political interest was discovered to be the most powerful predictor of COVID-19 news sharing on social media. The result approves first hypothesis $\mathrm{H} 1$ of this study. This outcome supports the recent findings of Karnowski et al. (2018) which explained that political interest among Twitter and Facebook users positively influenced their news sharing behaviour. In the context of present study, it depicts that an individual having political interest enjoys sharing COVID-19 information with others. In Pakistan, political interest has already been determined as strong political character of citizens (Mangi et al., 2019). Therefore, we can anticipate an increase in COVID-19 news sharing on social media by Pakistani social media users.

Our research further found political knowledge as second in position in developing COVID19 news sharing attitude in Pakistan. This finding approves H3. In this way we respond to the request of van Erkel and Aelst (2021) for investigating the impact of political knowledge on social media activities. We delineated COVID-19 news sharing on social media as social media activity. The results of the study clearly illustrate that political knowledge among social media users increase sharing of COVID-19 news. Based on these results, we are on the right side to claim that the more the people have political knowledge in Pakistan, the more they will actively disseminate COVID-19 related news content on social media.

Our findings also establish that political affiliation, that is one of the most prominent political behaviour in Pakistan (Shahzad \& Omar, 2021), positively influence the COVID-19 news sharing behaviour of the participants, that supports H2. In the study model, partisanship is the third significant predictor of COVID-19 news sharing. Strengthening the Huddy et al. (2010)'s findings our research concluded that party image and party support motivate people to share news in favour of their political party or against the rival party. Our study found similar trend on COVID-19 news sharing. In Pakistan massive controversy and political polarization was observed over the policy making in handling COVID-19 pandemic. A report published by International Crisis Group (2020) also mentioned the partisan impact on COVID-19 related policy making in Pakistan. Similar trend was observed on social media (Jahangir, 2020). Thus, the results of our study related to partisan's impact on COVID-19 news sharing portrays the real picture of Pakistani society.

In contrast to what we expected, political efficacy had no influence on COVID-19 news sharing behaviour. Therefore, $\mathrm{H} 4$ was not approved. This implies that individuals with sense and confidence of political competence avoid sharing COVID-19 news on social media. This outcome contradicts the results of prior researchers (e.g., Park \& Kaye, 2018; Lu \& Luqiu, 2020) who found significant impact of political efficacy on news sharing behaviour. Whereas our study found that reverse is true in case of COVID-19 news sharing. This situation develops perception that people with sense of political efficacy are sensitive in sharing COVID-19 related information. 
This study made a unique contribution by developing a link between political behaviour and public health domain in social media context, that was the much needed literary contribution in present global health crisis (Greer et al., 2020). Previous studies (e.g., Apuke \& Omar, 2020, 2021; Shang et al., 2021) often explored the effects of distinct forms of gratifications and health beliefs on sharing information related to public health on social media. We extended the existing literature and introduced distinct political behaviors as determinants of COVID-19 news sharing on social media.

Our study has some significant practical implications. Firstly, the research was conducted in the highly politicized society of Pakistan, where the tendencies to spread and believe the rumours, misinformation, myths, and conspiracies are pretty high (Ejaz et al., 2021). This track record depicts there are chances that people will immediately believe on the COVID-19 related news. That's why this study advises Pakistani social media users to be careful when sharing COVID-19-related news, carelessness might put the public at risk and create hindrance in curtailing the COVID-19 spread.

Secondly, the government of Pakistan has yet to implement consistent policy measures to stop the spread of new variants of COVID-19 pandemic and set such examples for social media trends which motivate people to follow the standard operating procedures (SOPs). Unfortunately, Violation of SOPs is largely observed in Pakistan (Raza, 2021). These violations have been intensively shared on social media that further provoke public to break the rules. Moreover, it is important to mention here that in present situation of the country where economic crisis, and political instability are already developing a depressive environment, the massive sharing of unauthentic COVID-19 content can worsen the mental health of the nation. Here the government's role is crucial. Unfortunately, instead of addressing this issue it adopted the opposite direction (Shah, 2021) that caused a lay man less responsive towards standard operating procedures.

\section{LIMITATIONS AND RECOMMENDATIONS}

Present study has some limitations which require to be addressed in future research. First, we recruited participants by using snowball sampling. Though we collected data from the respondents with different backgrounds still there are chances of sample biasness. Snowball sampling was chosen to avoid the risk of contracting COVID-19. These days after massive vaccination, government has already eased the lockdown. Considering this, future studies can use the multistage cluster sampling to get an unbiased sample. Second, this study tested political behaviours as antecedents of COVID-19 news sharing, it would be of scholarly interest to test same political behaviours as antecedents of COVID-19 fake news sharing. The phenomenon of COVID-19 fake news sharing has started capturing the market of empirical literature but less discussed in political domain. Future research can incorporate our variables, or they can also add some new variables in our model, to predict the COVID-19 fake news sharing among social media users. Finally, our study didn't examine the gender based COVID-19 news sharing behaviour. Multi group analysis (MGA) and the inclusion of gender as a moderator could be used in future studies.

\section{REFERENCES}

And1, S., Aytaç, S. E., \& Çarkoğlu, A. (2020). Internet and social media use and political knowledge: Evidence from Turkey. Mediterranean Politics, 25(5), 579-599. https://doi.org/10.1080/13629395.2019.1635816

Apuke, O. D., \& Omar, B. (2020). Modelling the antecedent factors that affect online fake news sharing on COVID-19: the moderating role of fake news knowledge. Health Education Research, 35(5), 490-503. https://doi.org/10.1093/her/cyaa030

Apuke, O. D., \& Omar, B. (2021). Fake news and COVID-19: modelling the predictors of fake news sharing among social media users. Telematics and Informatics, 56, 101475. https://doi.org/https://doi.org/10.1016/j.tele.2020.101475

Ardèvol-Abreu, A., Barnidge, M., \& Zúñiga, H. G. de. (2017). Communicative Antecedents of Political Persuasion: Political Discussion, Citizen News Creation, and the Moderating Role of Strength of Partisanship. Mass Communication and Society, 20(2), 169-191. https://doi.org/10.1080/15205436.2016.1244855

Bandura, A. (1977a). Autoeficacia: hacia una teoría unificadora del cambio de comportamiento. Revisión Psicológica, 84(2), 191-215. https://doi.org/10.1037/0033-295X.84.2.191

Bandura, A. (1977b). Self-Efficacy: Toward a Unifying Theory of Behavioral Change. Psychological 
Review, 84(2), 191-215. https://doi.org/10.1037//0033-295X.84.2.191

Bandura, A. (1986). Social Cognitive Theory. Prentice-Hall.

Bandura, A. (1995). Self-Efficacy in Changing Societies. Cambridge University Press. https://doi.org/https://doi.org/10.1017/CBO9780511527692

Bandura, A. (2001). The social cognitive theory of mass communication. Media Psychology, 61-90.

Becker, A. B., \& Copeland, L. (2016). Networked publics : How connective social media use facilitates political consumerism among LGBT Americans. Journal of Information Technology \& Politics, 13(1), 22-36.

Bilal, M. Z., Ali, A., \& Ullah, S. (2019). Effects of Media Exposure on the Political Polarization Patterns of Students in Pakistan. Global Social Sciences Review, 4(3), 292-298. https://doi.org/10.31703/gssr.2019(iv-iii).38

Bimber, B., Cunill, M. C., Copeland, L., \& Gibson, R. (2015). Digital Media and Political Participation: The Moderating Role of Political Interest Across Acts and Over Time. Social Science Computer Review, 33(1), 21-42. https://doi.org/10.1177/0894439314526559

Blustein, D. L., Duffy, R., Ferreira, J. A., Cohen-Scali, V., Cinamon, R. G., \& Allan, B. A. (2020). Unemployment in the time of COVID-19: A research agenda. Journal of Vocational Behavior, 119, 103436. https://doi.org/https://doi.org/10.1016/j.jvb.2020.103436

Bobbie, E. (2013). The Practice of Social Research (13th ed.).

Bridgman, A., Merkley, E., Loewen, P. J., Owen, T., Ruths, D., Teichmann, L., \& Zhilin, O. (2020). The causes and consequences of COVID-19 misperceptions: Understanding the role of news and social media. Harvard Kennedy School Misinformation Review, 1(3). https://doi.org/https://doi.org/10.37016/mr-2020-028

Chan, A. K. M., Nickson, C. P., Rudolph, J. W., Lee, A., \& Joynt, G. M. (2020). Social media for rapid knowledge dissemination: early experience from the COVID-19 pandemic. Anaesthesia, 75(12), 1579-1582. https://doi.org/https://doi.org/10.1111/anae.15057

Chan, M. (2018). Partisan Strength and Social Media Use Among Voters During the 2016 Hong Kong Legislative Council Election: Examining the Roles of Ambivalence and Disagreement. Journalism \& Mass Communication Quarterly, 95(2), 343-362. https://doi.org/10.1177/1077699017750857

Chen, Z., \& Chan, M. (2017). Motivations for Social Media Use and Impact on Political Participation in China: A Cognitive and Communication Mediation Approach. Cyberpsychology, Behavior, and Social Networking, 20(2), 83-90. https://doi.org/10.1089/cyber.2016.0174

Davey, G. (2020). The China-US blame game: claims-making about the origin of a new virus. Social Anthropology: The Journal of the European Association of Social Anthropologists = Anthropologie Sociale, 10.1111/1469-8676.12900. https://doi.org/10.1111/1469-8676.12900

Ejaz, W., Ittefaq, M., Seo, H., \& Naz, F. (2021). Factors associated with the belief in COVID-19 related conspiracy theories in Pakistan. Health, Risk $\backslash \&$ Society, 23(3-4), 162-178. https://doi.org/10.1080/13698575.2021.1929865

Fornell, C., \& Larcker, D. F. (1981). Evaluating Structural Equation Models with Unobservable Variables and Measurement Error. Journal of Marketing Research, 18(1), 39-50. https://doi.org/10.1177/002224378101800104

Fuchs, C. (2021). Donald Trump and COVID-19 on Twitter. In Communicating COVID-19 (pp. 191262). Emerald Publishing Limited. https://doi.org/10.1108/978-1-80117-720-720211011

Gannon, K. (2020). Trolls flood social media in Pakistan amid virus lockdown. AbcNews. https://abcnews.go.com/International/wireStory/trolls-flood-social-media-pakistan-amidvirus-lockdown-72650366

Greer, S. L., King, E. J., da Fonseca, E. M., \& Peralta-Santos, A. (2020). The comparative politics of COVID-19: The need to understand government responses. Global Public Health, 15(9), 1413-1416. https://doi.org/10.1080/17441692.2020.1783340

Grossman, G., Kim, S., Rexer, J. M., \& Thirumurthy, H. (2020). Political partisanship influences behavioral responses to governors' recommendations for COVID-19 prevention in the United States. Proceedings of the National Academy of Sciences, 117(39), 24144-24153. https://doi.org/10.1073/pnas.2007835117

Hair, J. F., Hault, G. T. M., Ringle, C. M., \& Sarstedt, M. (2017). A Primer on Partial Least Squares 
Structural Equation Modeling (PLS-SEM). Thousand Oaks. In Sage (2nd ed.).

Hair, J. F., Ringle, C. M., \& Sarstedt, M. (2011). PLS-SEM: Indeed a Silver Bullet. Journal of Marketing Theory and Practice, 19(2), 139-152. https://doi.org/10.2753/MTP10696679190202

Henseler, J., Hubona, G., \& Ray, P. A. (2016). Using PLS path modeling in new technology research: Updated guidelines. Industrial Management and Data Systems, 116(1), 2-20. https://doi.org/10.1108/IMDS-09-2015-0382

Henseler, J., Ringle, C. M., \& Sarstedt, M. (2015). A new criterion for assessing discriminant validity in variance-based structural equation modeling. Journal of the Academy of Marketing Science, 43(1), 115-135. https://doi.org/10.1007/s11747-014-0403-8

Himelboim, I., Lariscy, R. W., Tinkham, S. F., \& Sweetser, K. D. (2012). Social Media and Online Political Communication: The Role of Interpersonal Informational Trust and Openness. Journal of Broadcasting \& Electronic Media, 56(1), 92-115. https://doi.org/10.1080/08838151.2011.648682

Huddy, L., Mason, L., \& Aaroe, L. (2010). Measuring Partisanship as a Social Identity, Predicting Political Activism. Annual Meeting of the International Society for Political Psychology, January 2010.

Hussain, T. (2020). The coronavirus outbreak may hurt Imran Khan's political future. Aljazeera News Network. https://www.aljazeera.com/opinions/2020/4/8/the-coronavirus-outbreak-mayhurt-imran-khans-political-future

International Crisis Group. (2020). Pakistan's COVID-19 Crisis. https://d2071 andvip0wj.cloudfront.net/b162-pakistan-covid-19.pdf

Ittefaq, M., Hussain, S. A., \& Fatima, M. (2020). COVID-19 and social-politics of medical misinformation on social media in Pakistan. Media Asia, 47(1-2), 75-80. https://doi.org/10.1080/01296612.2020.1817264

Jahangir, R. (2020). Life in PTI's Social Media Bubble. Daily Dawn. https://www.dawn.com/news/1574529

Kalirajan, A., Narayanan, K. R., Ranjitsingh, A. J. A., Ramalakshmi, C., \& Parvathiraj, P. (2013). Bioprospecting medicinal plant Aerva lanata Juss. ex Schult. flowers for potential antimicrobial activity against clinical and fish-borne pathogens. Indian Journal of Natural Products and Resources, 4(3), 306-311. https://doi.org/10.1002/ejsp

Karnowski, V., Leonhard, L., \& Kümpel, A. S. (2018). Why Users Share the News: A Theory of Reasoned Action-Based Study on the Antecedents of News-Sharing Behavior. Communication Research Reports, 35(2), 91-100. https://doi.org/10.1080/08824096.2017.1379984

Katz, E., Blumler, J. G., \& Gurevitch, M. (1974). The uses of mass communications: Current perspectives on gratifications research. In Utilization of mass communication by the individual. (pp. 19-32). Sage Publications.

Khattak, D. (2020). Pakistan's Confused COVID-19 Response. The Diplomat. https://thediplomat.com/2020/06/pakistans-confused-covid-19-response/

Knoll, J., Matthes, J., \& Heiss, R. (2020). The social media political participation model: A goal systems theory perspective. Convergence, 26(1), 135-156. https://doi.org/10.1177/1354856517750366

Laato, S., Islam, A. K. M. N., Islam, M. N., \& Whelan, E. (2020). What drives unverified information sharing and cyberchondria during the COVID-19 pandemic? European Journal of Information Systems, 29(3), 288-305. https://doi.org/10.1080/0960085X.2020.1770632

Lobato, E. J., Powell, M., Padilla, L. M., \& Holbrook, C. (2020). Factors predicting willingness to share COVID-19 misinformation. Lab, 11, 2413.

LaRose, R., \& Eastin, M. S. (2004). A Social Cognitive Theory of Internet Uses and Gratifications: Toward a New Model of Media Attendance. Journal of Broadcasting \& Electronic Media, 48(3), 358-377. https://doi.org/10.1207/s15506878jobem4803_2

Lu, S., \& Luqiu, L. R. (2020). Does political efficacy equally predict news engagement across countries? A multilevel analysis of the relationship among internal political efficacy, media environment and news engagement. New Media \& Society, 22(12), 2146-2165. 
https://doi.org/10.1177/1461444819888417

Mahmood, Q. K., Jafree, S. R., Mukhtar, S., \& Fischer, F. (2021). Social media use, self-efficacy, perceived threat, and preventive behavior in times of COVID-19: results of a cross-sectional study in Pakistan. Frontiers in Psychology, 12, 2354

Mangi, S. N., Shah, N., \& Mahesar, S. A. (2019). Political Interests Of Public In Pakistan. Grassroots, $52(1)$.

Marin, L. (2020). Three contextual dimensions of information on social media: lessons learned from the COVID-19 infodemic. Ethics and Information Technology. https://doi.org/10.1007/s10676-020-09550-2

Mustapha, L. K., \& Omar, B. (2020). Do social media matter? Examining social media use and youths' political participation during the 2019 Nigerian general elections. The Round Table, 109(4), 441-457. https://doi.org/10.1080/00358533.2020.1788766

Naseem, H. (2020). "Mixed messages to blame for SOPs violation." The Express Tribune.

Park, C. S., \& Kaye, B. K. (2018). News Engagement on Social Media and Democratic Citizenship: Direct and Moderating Roles of Curatorial News Use in Political Involvement. Journalism \& Mass Communication Quarterly, 95(4), 1103-1127. https://doi.org/10.1177/1077699017753149

Park, N., Kee, K., \& Valenzuela, S. (2009). Being immersed in social networking environment: Facebook groups, uses and gratifications, and social outcomes. CyberPsychology \& Behavior, 12(6), 729-733. https://doi.org/10.1089/cpb.2009.0003

Pei, Z., Pan, Y., \& Skitmore, M. (2018). Political Efficacy, Social Network and Involvement in Public Deliberation in Rural China. Social Indicators Research, 139(2), 453-471. https://doi.org/10.1007/s11205-017-1737-7

Radwan, E., Radwan, A., \& Radwan, W. (2020). The role of social media in spreading panic among primary and secondary school students during the COVID-19 pandemic: An online questionnaire study from the Gaza Strip, Palestine. Heliyon, 6(12), e05807. https://doi.org/https://doi.org/10.1016/j.heliyon.2020.e05807

Ramayah, T., Cheah, J., Chuah, F., Ting, H., \& Memon, M. A. (2018). Partial Least Squares Structural Equation Modeling (PLS-SEM) using SmartPLS 3.0 (2nd ed.). Pearson.

Raosoft. (2004). Raosoft Sample Size Formula. http://www.raosoft.com/samplesize.html

Raza, S. I. (2021). Criticism as PM holds meeting with media team. Daily DAWN. https://www.dawn.com/news/1614660

Ringle, C. M., Da Silva, D., \& Bido, D. D. S. (2014). Structural Equation Modeling with the smartPLS. Revista Brasileira de Marketing, 13(2), 56-73. https://doi.org/10.5585/remark.v13i2.2717

Ringle, C. M., Wende, S., \& Will, A. (2005). SmartPLS 2.0 (Beta). https://www.smartpls.com/

Romano, S., Galante, H., Figueira, D., Mendes, Z., \& Rodrigues, A. T. (2021). Time-trend analysis of medicine sales and shortages during COVID-19 outbreak: Data from community pharmacies. Research in Social and Administrative Pharmacy, 17(1), 1876-1881. https://doi.org/https://doi.org/10.1016/j.sapharm.2020.05.024

Rosengren, K. E. (1974). Uses and gratifications: A paradigm outlined. In B. JG \& K. E (Eds.), The Uses of Mass Communication (pp. 269-286).

Rubin, A. M. (2009). Uses and Gratifications: An Evolving Perspective of Media Effects. In R. L.Nabi \& M. B. Oliver (Eds.), The SAGE Handbook of Media Processes and Effects (pp. 147-159). Sage publications.

Sahni, H., \& Sharma, H. (2020). Role of social media during the COVID-19 pandemic: Beneficial, destructive, or reconstructive? International Journal of Academic Medicine, 6(2). https://doi.org/10.4103/IJAM.IJAM_50_20

Sekaran, U., \& Bougie, R. (2020). Research Methods for Business: A Skill Building Approach (8th ed.). John Wiley \& Sons Ltd.

Shah, B. (2021). Slip-ups, gaffes, false claims from PTI ministers and officials. Geo TV. https://www.geo.tv/latest/368037-slip-ups-gaffes-false-claims-all-the-way-from-the-top

Shahzad, S., \& Omar, B. (2021). Social network matters: The influence of online social capital on youth political participation in Pakistan. Journal of Information Technology $\backslash \&$ Politics, $O(0)$, 1-13. https://doi.org/10.1080/19331681.2021.1900018 
Shang, L., Zhou, J., \& Zuo, M. (2021). Understanding older adults' intention to share health information on social media: the role of health belief and information processing. Internet Research, 31(1), 100-122. https://doi.org/10.1108/INTR-12-2019-0512

Skoric, M., \& Zhang, N. (2019). Opinion Leadership, Media Use, and Environmental Engagement in China. International Journal of Communication, 13.

Strömbäck, J., Djerf-Pierre, M., \& Shehata, A. (2012). The Dynamics of Political Interest and News Media Consumption: A Longitudinal Perspective. International Journal of Public Opinion Research, 25(4), 414-435. https://doi.org/10.1093/ijpor/eds018

Thompson, N., Wang, X., Daya, P., Thompson, N., \& Wang, X. (2020). Determinants of News Sharing Behavior on Social Media. Journal of Computer Information Systems, 60(6), 593601. https://doi.org/10.1080/08874417.2019.1566803

Toffolutti, V., Stuckler, D., \& McKee, M. (2020). Is the COVID-19 pandemic turning into a European food crisis? European Journal of Public Health, 30(4), 626-627. https://doi.org/10.1093/eurpub/ckaa101

Turner, J. C. (2010). Social categorization and the self-concept: A social cognitive theory of group behavior. In Rediscovering social identity. Psychology Press.

van Erkel, P. F. A., \& Aelst, P. Van. (2021). Why Don't We Learn from Social Media? Studying Effects of and Mechanisms behind Social Media News Use on General Surveillance Political Knowledge. Political Communication, 38(4), 407-425. https://doi.org/10.1080/10584609.2020.1784328

Ward, J. K., Alleaume, C., Peretti-Watel, P., Peretti-Watel, P., Seror, V., Cortaredona, S., Launay, O., Raude, J., Verger, P., Beck, F., Legleye, S., L'Haridon, O., \& Ward, J. (2020). The French public's attitudes to a future COVID-19 vaccine: The politicization of a public health issue. Social Science \& Medicine, 265, 113414. https://doi.org/https://doi.org/10.1016/j.socscimed.2020.113414

Wei, L., \& Zhao, L. (2017). Social Media Use, Political Efficacy, and Political Participation in China: The Moderating Role of Need for Orientation. New Media and Chinese Society, November, $55-73$.

World Health Organisation. (2021). China Situation. WHO Health Emergency Dashboard. https://covid19.who.int/region/wpro/country/cn

World Health Organization. (2021). United States of America Situation. WHO Health Emergency Dashboard. https://covid19.who.int/region/amro/country/us

Yamamoto, M., Kushin, M. J., \& Dalisay, F. (2017). Social Media and Political Disengagement Among Young Adults: A Moderated Mediation Model of Cynicism, Efficacy, and Social Media Use on Apathy. Mass Communication and Society, 20(2), 149-168. https://doi.org/10.1080/15205436.2016.1224352

Yamey, G., \& Gonsalves, G. (2020). Donald Trump: a political determinant of covid-19. BMJ, 369. https://doi.org/10.1136/bmj.m1643 